\title{
АНАЛІЗ ДІАГНОСТИКИ РІВНЯ ІНТЕГРАЛЬНОГО ПОКАЗНИКА ЗАГАЛЬНИХ ІНТЕЛЕКТУАЛЬНИХ ЗДІБНОСТЕЙ КАНДИДАТІВ НА СЛУЖБУ В НАЦІОНАЛЬНУ ПОЛІЦІЮ ТА НАВЧАННЯ У ЗАКЛАДАХ ОСВІТИ МВС УКРАЇНИ
}

УДК: 159,923:351.74

\section{Смірнова Олъга Михайлівна}

Кандидат психологічних наук, доцент кафедри психології та педагогіки Одеського державного університету внутрішніх справ, м. Одеса (Украӥна)

\begin{abstract}
Анотація. Статтю присвячено аналізу діагностики рівня інтегрального показника загальних інтелектуальних здібностей кандидатів на службу в Національну поліцію або навчання y закладах вищсої освіти Міністерства внутрішніх справ Украӥни за методикою «Короткий орієнтовний відбірковий тест» (КОT) під час професійно-психологічного відбору. Здійснено теоретичний аналіз процедури та діагностичного інструментарію щзодо професійного психологічного відбору до поліщії в Украӥні. На основі проведеного дослідження та аналізу емпіричних даних визначено, щзо найбільш суттєвий вплив на величину інтегрального показника загальних інтелектуальних здібностей має освітній рівень та стать кандидатів, а також установлено оцінки індивідуального показника методики для окремих категорій кандидатів.
\end{abstract}

Ключові слова: інтегральний показник загальних інтелектуальних здібностей, Національна поліч̧ія, професійно-психологічний відбір кандидатів на службу в Національну поліцію, професійно-психологічний відбір кандидатів на навчання у закладах вищої освіти Міністерства внутрішніх справ України.

Постановка проблеми. Професійний психологічний відбір найбільш придатних кандидатів $\epsilon$ важливим етапом добору (конкурсу) на службу в Національній поліції та навчання у закладах вищої освіти МВС України (далі - ЗВО МВС). Для Національної поліції проблема добору працівників є вельми актуальною [1, с. 12]. Відповідно до норм Закону України «Про Національну поліцію» від
2 липня 2015 р. на службу або навчання працівники служб психологічного забезпечення органів і підрозділів Національної поліції та 3ВО МВС повинні відібрати кандидатів, які здатні професійно виконувати правоохоронні функції щодо забезпечення публічної безпеки і порядку, охорони прав і свобод людини, а також інтересів суспільства і держави, протидії злочинності надання в межах, визначених 
законом, послуг із допомоги особам, які з особистих, економічних, соціальних причин або внаслідок надзвичайних ситуацій потребують такої допомоги [2].

Із метою прогнозування професійної придатності і освіченості в різного роду відомствах і навчальних закладах як у нас у країні, так і за кордоном широко використовуються тести оцінки рівня інтелекту. Ці тести умовно можна розділити на дві групи: 1) тести оцінки загального інтелекту (індивідуальні (тест Векслера і ін.); групові (тест Вандерліка, Равена і ін.); 2) спеціалізовані тести для оцінки окремих якостей розумової діяльності.

Працівниками служб психологічного забезпечення органів і підрозділів Національної поліції та ЗВО МВС відповідно до норм чинного законодавства [2-6] як методика, що дозволяє отримати результати про інтелектуальні можливості кандидата на посаду або на навчання у ЗВО МВС, використовуються «Прогресивні матриці Равена», певні переваги яких зумовили тривале і в цілому успішне застосування даної методики.

Поряд із цим у зв'язку із соціальноекономічними змінами, проведенням реформи правоохоронних органів в українському суспільстві, а також технічним прогресом працівнику Національної поліції, окрім загальних здібностей до логічного мислення, необхідний високий рівень загальної обізнаності, ерудиції, стійкості розумової діяльності в умовах емоційної напруженості професійної право- охоронної діяльності, становить інтерес Короткий орієнтовний відбірковий тест (далі КОТ) В. Н. Бузіна, Є. Ф. Вандерліка [9], який дозволяє в стислі строки провести обстеження значної кількості кандидатів та є простим в обробленні.

У теперішній час одним із критеріїв професійного відбору кандидатів на службу до Національної поліції та навчання у ЗВО MBC є аспект психологічної придатності кандидата. Цей факт свідчить про наявність правового інституту та професійнопсихологічного відбору претендентів [1, с. 12].

Варто зазначити, що на теперішній час в Україні процедура та діагностичний інструментарій професійного психологічного відбору до поліції тільки формується, а тому потребують ретельної уваги методики, які дозволять у короткі строки за реально існуючих умов досягти найкращого результату. Зупинимося на аналізі методики КОТ, яка дозволяє швидко отримати розгорнуту характеристику адаптації особистості кандидата на посаду в поліції у світі в цілому, а також передбачає психодіагностику таких параметрів інтелекту: здатність до узагальнення й аналізу, гнучкість мислення, швидкість і точність сприйняття матеріалу, грамотність, вибір оптимальної стратегії і т. ін.

\section{Аналіз останніх досліджень і публіка-}

цій. Дослідження багатьох авторів показують, що поліцейському потрібно мати необхідні 
для роботи професійно-важливі індивідульнопсихологічні якості [10, с.18]. Однак, фундаментом для отримання необхідних професійно-важливих якостей і успішного виконання діяльності є здібності людини до навчання. Питання здібностей особистості працівників правоохоронних органів до навчання були предметом наукових досліджень, зокрема В. Г. Андросюка, О. М. Бандурки, Б. В. Барка, С. П. Бочарової, В. Л. Васильєва, А. В. Дулова, М.І. Єникеєва, Н. І. Клименко, В. О. Коновалової, О. Г. Ратинова, В. В. Романова, В. О. Соболєва та ін. В їх роботах розкриваються окремі підходи до структури професійно-важливих якостей працівників ОВС, аналізуються психологічні засади їх успішної правоохоронної діяльності тощо.

Так у працях В. I. Барка, С. А. Бодрова, O. М. Боросивої, В. О. Лефтерова, Ю. В. Осіпової, Ю. Є. Писаренка та інших науковців досліджуються структури професійних здібностей i побудови їх профілів; Л. М. Карамушка, Є. О. Климов, Д. Г. Лаптєв, А. К. Маркова аналізують здібності працівників ОВС в різних аспектах в контексті психології професійної діяльності, психології управління.

Такі автори, як О. Ф. Андрійко, Л. М. Балабанова, О. М. Бандурка, В. І. Барко, A. M. Большакова, I. В. Воробйова, О. О. Свдокімова, І. В. Жданова, О. В. Іванова, М. А. Кузнєцов, О. В. Лавріненко, С. О. Ларіонов, П. В. Макаренко,
О. А. Мартиненко, Я. В. Марцегора, Н. Е. Мілорадова, А.В. Нежута, Г.В. Попова, О. М. Смірнова, О.В. Ступакова, О.І. Федоренко, Л.О. Шевченко та ін. досліджували здібності чоловіків і жінок працівників ОВС.

Здібності є одним з найбільших загальних психологічних понять. Багато авторів надали йому розгорнуті визначення. «Український педагогічний словник» С. У. Гончаренка визначає здібності людини як «стійкі індивідуальні властивості людини, які є внутрішньою умовою їі успішної діяльності. Здібності поділяються на загальні - такі, що виявляються у всякій діяльності та спеціальні, що характерні для певних іiі видів [11, с. 135].

Філософ К. А. Гельвеція, запевняє, що люди від природи мають однакові здібності, які розвиваються в процесі виховання [12, с. 43]. Протилежну точку зору має Д. Дідро, який вважає, що люди народжуються 3 різними здібностями, які розвиваються залежно від активності особистості та здатності самовдосконалюватися [13, с.115].

У психологічному словнику А. В. Петровського здібності людини визначено як індивідуально-психологічні особливості, які $є$ передумовою успішного виконання певної діяльності [14, с.381].

На думку С. Л. Рубінштейна, здібності - це складне синтетичне утворення, яке включає в себе цілий ряд даних, без яких лю- 
дина не була б знатна до будь-якої діяльності, і властивостей, які формуються певним чином в процесі організованої діяльності [15, с. 62].

Б. М. Теплов запропонував три емпіричних по суті ознаки, які лягли в основу визначення здібностей, що найбільш часто використовуються фахівцями: здібності - це індивідуально-психологічні особливості, що вирізняють одну людину від іншої; тільки ті особливості, які мають відношення до успішності виконання діяльності; здібності не зводяться до знань, умінь і навичок, які вже сформовані у людини, хоча і обумовлюють легкість і швидкість придбання цих знань i навичок $[16$, c. 23$]$.

Варто зазначити, що успішність виконання діяльності визначають також і мотивація, і особистісні особливості, що й спонукало К. К. Платонова віднести до здібностей будьякі властивості психіки, які у тій чи іншій мірі визначають успіх у конкретній діяльності $[17$, с. 43]. Однак, 3 точки зору Б.М. Теплова, крім успіху в діяльності, здатність детермінує швидкість і легкість оволодіння діяльністю і це змінює становище в визначенням: легкість навчання може залежати від мотивації, але почуття легкості (інакше «суб'єктивна ціна», переважання труднощів) при навчанні, швидше зворотньопропорційна мотивації напрузі [16, с. 31].

Мета наукової статті полягає в тому, щоб на основі аналізу емпіричних даних діагностики визначити фактори впливу на показ- ник ІП, а також з'ясувати критерії оцінки категорії Інтегрального показника загальних розумових здібностей (далі - IП) за методикою КОТ при відборі і професійній орієнтації кандидатів на службу в Національну поліцію або навчання у $3 \mathrm{BO} \mathrm{MBC}$.

\section{Виклад основного матеріалу та ре-} зультатів дослідження. Методику КОТ було розроблено як відбіркову методику для людей, які претендують на подальше навчання, i є адаптацією тесту Вандерліка [9, с. 12]. Методика КОТ використовується при попередньому відборі та розподілі кадрів у промисловості, армії, поліції, системі освіти, профорієнтаційній роботі, психодіагностиці навченості і ділових якостей особистості [18, с. 5]. В основу тесту закладено модель структури загальних здібностей [7, с. 13].

\section{Методика КОТ дає змогу визначити не} тільки значення інтегрального показника загального рівня інтелектуального розвитку, а й здібності до навчання. При цьому під «навчанням» розуміють «пізнавальну активність індивідуума і його можливості до засвоєння нових знань, дій, подібних форм діяльності» [19, с. 24].

Таким чином, можна припустити, що чим більш розвинені у працівника Національної поліції здатності до навчання, тим успішніше він виконує професійну поліцейську діяльність, швидше іiі опановує, а процес оволодіння діяльністю і сама діяльність даються йому суб'єктивно легше, ніж інших працівни- 
кам, які не володіють такими здібностями.

Отже, тест КОТ призначено для відбору осіб із високою здатністю до навчання, у яких швидко формуються спеціальні навички й уміння, пластично здійснюється внутрішня перебудова стереотипу дій при зміні й ускладненні умов діяльності.

Методика КОТ складається з 50-ти пунктів і представлена завданнями на розв'язання арифметичних задач, установлення аналогій, розуміння прислів 'їв і приказок, силогістичних операцій, а також завдання на стійкість уваги і просторового мислення. Тест дає можливість 3'ясувати:

- інтегральний показник загальних здібностей особистості (далі - ІП);

- показники по субшкалах для оцінки окремих показників, що відображають інтелектуальний розвиток особистості, зокрема: piвень довільності, високої концентрації і розподілу уваги (1); загальний рівень обізнаності й розвитку лінгвістичних здібностей (якість гуманітарної освіченості) (2); рівень освіченості в галузі точних наук (3); рівень просторового орієнтування й абстрактно-логічного мислення (4); інформованість (5); вербальний інтелект (6); умовиводи (7); гнучкість мислення (8); смислові узагальнення (9); технічний інтелект (10); числові операції (11); числові закономірності (12); просторові операції (просторова уява) (13); здатність узагальнення та аналізу матеріалу (14); емоційні компоненти мислення (15); швидкість і точність сприй- няття (16); вживання мови (грамотність) (17); математичні здібності (18).

Емпірична база дослідження - результати психодіагностики 131 особи (99 чоловіків та 32 жінки) віком від 19 до 22 років. Строк служби - 3 роки. Дослідження проводилось на базі ГУНП в Одеській області та Одеського державного університету внутрішніх справ (далі - ОДУВС). Випробувані були представлені курсантами третього курсу факультету 3 підготовки кадрів кримінальної поліції (далі КП), які навчаються за денною формою на базі ОДУВС (69 осіб) та слухачами 1-го курсу ОДУВС заочного відділення (62 особи), які проходять службу в підрозділах патрульної поліції ГУНП в Одеській області (далі - ПП).

Результати та їх обговорення. При аналізі результатів тесту КОТ виявилося, що кількість виконаних завдань тесту пов'язано з такими характеристиками особистості, як стать, вік і освіта. При цьому найбільш суттєвий вплив на величину інтегрального показника методики (загальна кількість правильно ви-

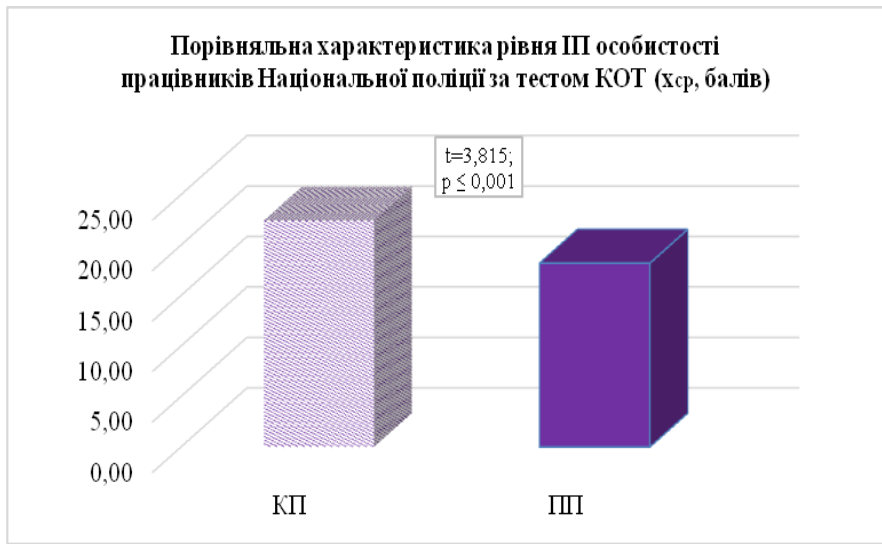

Pис. 1 
конаних завдань) справляє освітній рівень кандидатів.

Результати емпіричного дослідження у сфері діагностики ІП (Рис. 1) свідчать про наявність статистично значимих відмінностей. Дані емпіричного дослідження, проведеного за допомогою методики КОТ, доводять, що курсанти КП, які здобувають вищу освіту, у порівнянні з працівниками ПП, мають вищий рівень інтелектуального розвитку та кращі здібності до подальшого навчання та пізнаваль-

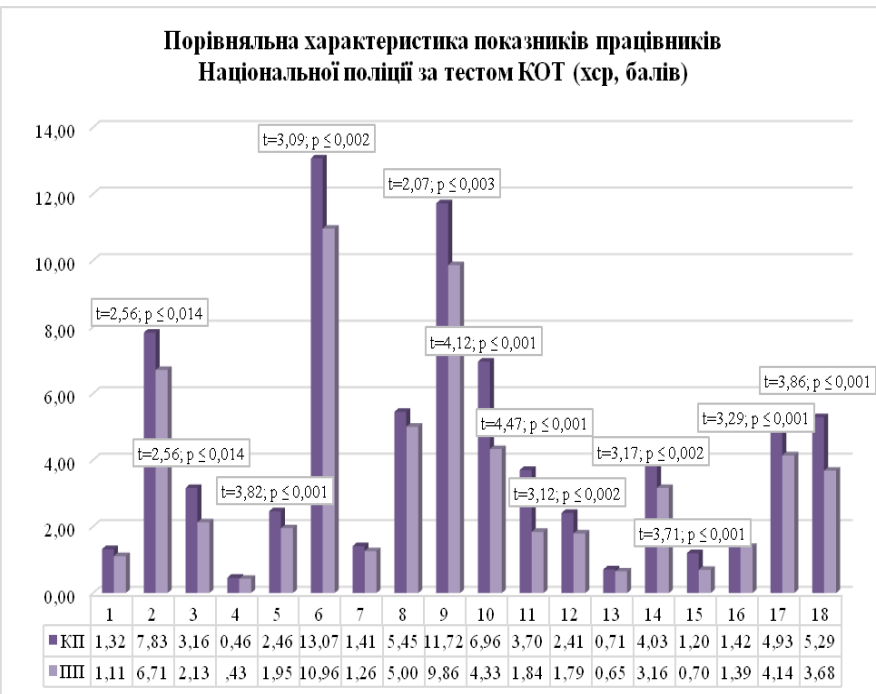

\section{Рис. 2.}

ної діяльності, тобто мають більш значну пізнавальну активність та можливості до засвоєння нових знань, дій, схожих форм діяльносTi $(\mathrm{p} \leq 0,001)$.

Діагностика критичних точок інтелекту (Рис. 2) також доводить, що курсанти КП у порівнянні з працівниками ПП мають вищий загальний рівень обізнаності й розвитку лінгвістичних здібностей та $є$ більш гуманітарно освіченими ( $\mathrm{p} \leq 0,014)$; більш успішно вико- нують числові завдання на встановлення закономірностей із геометричними фігурами $(\mathrm{p} \leq 0,001) ; \epsilon$ більш інформованими $(\mathrm{p} \leq 0,001)$; мають глибший зв'язок між функціонуванням інтелекту і різними лінгвістичними навичками ( $\mathrm{p} \leq 0,002)$; володіють вищими здібностями смислових узагальнень ( $\mathrm{p} \leq 0,003)$; мають вищий рівень технічного інтелекту, тобто більше володіють комп’ютерними технологіями, Інтернетом тощо (p $\leq 0,001)$; значно краще володіють числовими операціями $(\mathrm{p} \leq 0,001)$ та числовими закономірностями $(\mathrm{p} \leq 0,002)$; мають кращі здібності узагальнення й аналізу матеріалу, що дає їм можливість абстрагуватися від конкретних фраз та перейти у сферу інтерпретації смислів, знайти перетин смислів, а потім зно-

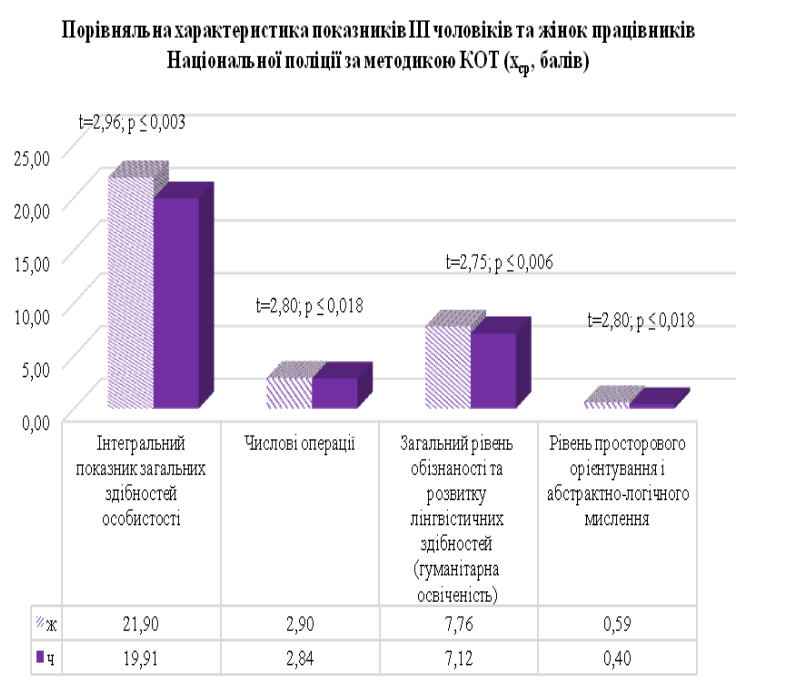

Pис. 3

ву повернутися до конкретних фраз ( $\leq \leq 0,002)$; мають значно нижчий рівень емоційної деструкції розумових проце- 
Таблиия 1.

\section{Величина показника рівня загальних інтелектуальних здібностей для працівників} Національної поліції

\begin{tabular}{|l|l|l|l|l|l|}
\hline \multirow{2}{*}{$\begin{array}{l}\text { Рівень / рекоме- } \\
\text { ндація }\end{array}$} & Низький & $\begin{array}{l}\text { Нижче серед- } \\
\text { нього }\end{array}$ & Середній & $\begin{array}{l}\text { Вище серед- } \\
\text { нього }\end{array}$ & Високий \\
\cline { 2 - 6 } & 1 & 2 & 3 & 4 & 5 \\
\cline { 2 - 6 } & $\begin{array}{l}\text { Рекомендується умовно (мін. } \\
\text { відповідає) }\end{array}$ & $\begin{array}{l}\text { Рекомендується } \\
\text { (в основному відповідає) }\end{array}$ & $\begin{array}{l}\text { Рекомендується в 1 } \\
\text { чергу (повністю відпо- } \\
\text { відає) }\end{array}$ \\
\hline $\begin{array}{l}\text { Вища освіта } \\
\text { КП) }\end{array}$ & $\geq 11$ & $12-16$ & $17-27$ & $28-33$ & $33-39$ \\
\hline $\begin{array}{l}\text { Середня та спе- } \\
\text { ціальна освіта } \\
\text { (ПП) }\end{array}$ & $\geq 12$ & $13-17$ & $18-24$ & $25-30$ & $31-38$ \\
\hline
\end{tabular}

сів ( $\mathrm{p} \leq 0,002)$; уміють правильно використо- ліції свідчать про наявність гендерних відмінвувати мову, є більш грамотними, краще зна- ностей між жінками і чоловіками. Так порів-

Таблиця 2.

Величина та характеристика показника рівня загальних інтелектуальних здібностей для працівників Національної поліції (балів, \%)

\begin{tabular}{|c|c|c|c|c|c|c|}
\hline \multirow{3}{*}{ Рівень / рекомендація } & \multicolumn{2}{|c|}{ Вища освіта } & \multicolumn{4}{|c|}{ Середня та спец. освіта } \\
\hline & \multirow{2}{*}{ \% за рівнем } & \multicolumn{2}{|c|}{ Всього } & \multirow{2}{*}{ \% за рівнем } & \multicolumn{2}{|c|}{ Всього } \\
\hline & & $\mathbf{n}$ & $\%$ & & $\mathbf{n}$ & $\%$ \\
\hline \multicolumn{7}{|c|}{ А) Рекомендується умовно (мінімально відповідає) } \\
\hline Низький рівень & 2,9 & \multirow{2}{*}{16} & \multirow{2}{*}{23,2} & 22,8 & \multirow{2}{*}{29} & \multirow{2}{*}{36,8} \\
\hline Нижче середнього & 13,2 & & & 24,6 & & \\
\hline \multicolumn{7}{|c|}{ Б) Рекомендується } \\
\hline Середній (в основному відповідає) & 66,2 & \multirow{3}{*}{53} & \multirow{3}{*}{76,8} & 33,3 & \multirow{3}{*}{27} & \multirow{3}{*}{48,2} \\
\hline Вище середнього (в основному відповідає) & 16,2 & & & 15,8 & & \\
\hline Високий в 1 чергу (повністю відповідає) & 1,5 & & & 3,5 & & \\
\hline
\end{tabular}

ють іноземну мову $(\mathrm{p} \leq 0,001)$; мають вищий рівень математичних здібностей $(\mathrm{p} \leq 0,001)$.

Результати емпіричного дослідження особливостей інтегрального показника загальних здібностей працівників Національної по- няльна характеристика показників за тестом КОТ свідчить про існування статистично значимих відмінностей (Табл. 3).

Аналіз даних рис. 3 доводить, що жінки $\epsilon$ більш інтелектуально здібними ( $\mathrm{p} \leq 0,003)$;

\section{Характеристика показника рівня загальних інтелектуальних здібностей працівників}

Таблиия 3.

\section{Національної поліції (\%)}

\begin{tabular}{|l|c|c|c|c|}
\hline Рекомендація & Вища освіта & $\begin{array}{c}\text { Середня та спец. } \\
\text { освіта }\end{array}$ & 甲емп & \\
\cline { 1 - 3 } Рекомендується & 76.8 & 48.2 & 2,921 & \multirow{2}{*}{0,001} \\
\hline Умовно & 23.2 & 36.8 & \\
\hline
\end{tabular}


мають вищий рівень гуманітарної освіченості $(p \leq 0,006)$, просторового орієнтування і абстрактно-логічного мислення $(\mathrm{p} \leq 0,018)$, а також $є$ більш здатними до числових операцій $(\mathrm{p} \leq 0,04)$.

Величина відхилення ІП конкретного кандидата від середньостатистичного показника однорідної з ним групи визначає оцінку індивідуального показника методики. Пропонується використовувати 5 категорій оцінки індивідуального результату в тесті залежно від ступеня його відхилення від середньостатистичного. Величину та характеристику IП надано в Табл. 1 з урахуванням наявності рівня освіти.

Аналіз емпіричних даних Табл. 2, 3 свідчить, що серед працівників КП, які мінімально відповідають професійним вимогам і можуть бути умовно рекомендованими кандидатами, - 23,2 \%, ПП - 36,8 \% (А); мають бути рекомендованими і відповідають професійним вимогам КП - 76,8 \%, ПП - 48,2 \% (Б). Отримане емпіричне значення $\varphi_{\text {емп }}=2.921$ ( $\varphi_{\text {крит }}=$

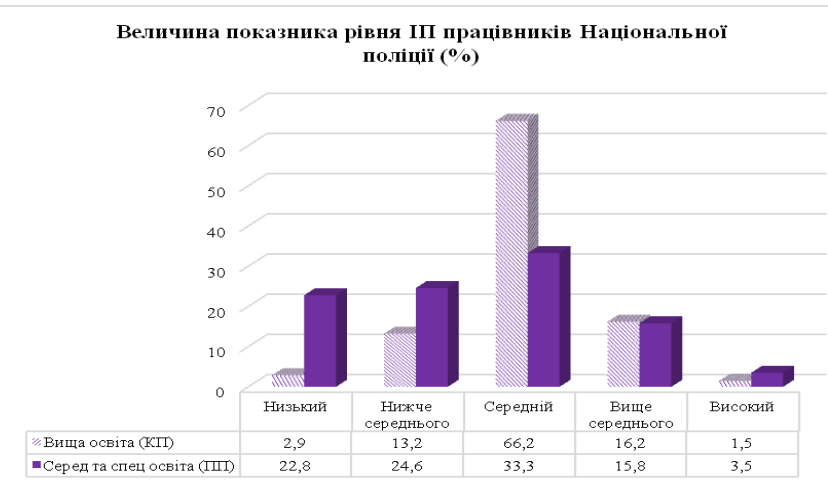

Puc. 4
$1,64)$ знаходиться в зоні значимих відмінностей $(\mathrm{p} \leq 0,001)$, тобто можна стверджувати, що в вибірках присутні достовірні відмінності ІП, які визначаються наявністю або відсутністю вищої освіти.

Як видно з Рис. 4, статистичний розподіл числа виконаних завдань працівниками КП має симетричний вигляд, близький до нормального, що дозволяє прогнозувати відсоток відсіву кандидатів.

Варто зауважити, що низький результат може бути недостатньо надійним унаслідок можливих помилок у дотриманні умов тестування і розумінні інструкції. Тому невисокий результат тестування за даною методикою в жодній мірі не може бути ознакою психологічної професійної непридатності до будь -якої спеціальності. Тільки тестування за допомогою інших методів, може надати достовірну інформацію про психологічні протипоказання до тих чи інших професій.

Цей же принцип застосовується і при оцінці показників по субшкалах методики при диференційованому аналізі особливостей розумової діяльності, а також при діагностиці гендерних відмінностей ІП чоловіків і жінок кандидатів на службу в Національній поліції або навчання у ЗВО МВС.

Аналіз емпіричних даних табл. 4 свідчить, що частка жінок, які мінімально відповідають професійним вимогам і можуть бути умовно рекомендованими кандидатами, становить $24,1 \%$, чоловіків - 39,6 \% (А); мають бу- 
ти рекомендованими і відповідають професій- чання) в Національній поліції. По-друге, проним вимогам: жінки - 75,9 \%, чоловіки - фесійний відбір і орієнтація кандидата на слу-

Таблиия 4.

Величина та характеристика показника ІІ чоловіків і жінок - кандидатів до служби в Національній поліції або навчання у ЗВО МВС (балів, \%)

\begin{tabular}{|c|c|c|c|c|c|c|c|c|}
\hline \multirow{3}{*}{ Рівень / рекомендація } & \multicolumn{4}{|c|}{ Жінки } & \multicolumn{4}{|c|}{ Чоловіки } \\
\hline & \multirow{2}{*}{ Балів } & \multirow{2}{*}{$\%$} & \multicolumn{2}{|c|}{ Всього } & \multirow{2}{*}{ Балів } & \multirow{2}{*}{$\%$} & \multicolumn{2}{|c|}{ Всього } \\
\hline & & & $\mathbf{n}$ & $\%$ & & & $\mathbf{n}$ & $\%$ \\
\hline \multicolumn{9}{|c|}{ А) Рекомендується умовно (мінімально відповідає) } \\
\hline Низький рівень & $\geq 11$ & 6,9 & \multirow{2}{*}{7} & \multirow{2}{*}{24,1} & $\geq 12$ & 12,0 & \multirow{2}{*}{38} & \multirow{2}{*}{39,6} \\
\hline Нижче середнього & $12-16$ & 17,2 & & & $13-17$ & 18,4 & & \\
\hline \multicolumn{9}{|c|}{ Б) Рекомендусться } \\
\hline Середній (в основному відповідає) & $17-27$ & 58,6 & \multirow{3}{*}{22} & \multirow{3}{*}{$\mathbf{7 5 , 9}$} & $\overline{18-24}$ & $\overline{51,2}$ & \multirow{3}{*}{58} & \multirow{3}{*}{60,4} \\
\hline Вище середнього (в основному відповідає) & $28-33$ & 10,3 & & & $25-30$ & 16,0 & & \\
\hline $\begin{array}{l}\text { Високий в першу чергу (повністю відпові- } \\
\text { дає) }\end{array}$ & $33-39$ & 6,9 & & & $31-38$ & 2,4 & & \\
\hline
\end{tabular}

$60,4 \%$ (Б). Отримане емпіричне значення $\varphi_{\text {емп }}$ $=2,369\left(\varphi_{\text {крит }}=1,64\right)$ знаходиться в зоні значи-

Таблиия 5.

Характеристика рівня загальних інтелектуальних здібностей чоловіків і жінок працівників Національної поліції або навчання у ЗВО МВС (\%)

\begin{tabular}{|l|c|c|c|c|}
\hline $\begin{array}{l}\text { Рекомен- } \\
\text { дація }\end{array}$ & Жінки & $\begin{array}{c}\text { Чолові- } \\
\text { ки }\end{array}$ & $\varphi_{\text {еми }}$ & $\mathbf{p}$ \\
\cline { 1 - 3 } $\begin{array}{l}\text { Рекомен- } \\
\text { дується }\end{array}$ & 75,9 & 60,4 & \multirow{2}{*}{2,369} & $\begin{array}{c}0,00 \\
1\end{array}$ \\
\cline { 1 - 3 } Умовно & 24,1 & 39,6 & & \\
\hline
\end{tabular}

мих відмінностей $(\mathrm{p} \leq 0,001)$, тобто можна стверджувати, що у вибірках присутні достовірні відмінності ІП, які визначається статтю кандидата (Табл. 5).

Необхідно чітко диференціювати два завдання, що стоять перед фахівцямипсихологами, які займаються професійним відбором. По-перше, відсів кандидатів із прикордонною розумовою відсталістю і, відповідно, непридатних для несення служби (або нав- жбу в Національній поліції залежно від вимог до інтелектуального рівня співробітника, що висуваються в тому чи іншому підрозділі.

Для виконання першого завдання на підставі проведеного аналізу емпіричних даних тесту нами розроблено та запропоновано критерії, подані в табл. 1 та 4. При цьому:

- особи, які показали результати, що

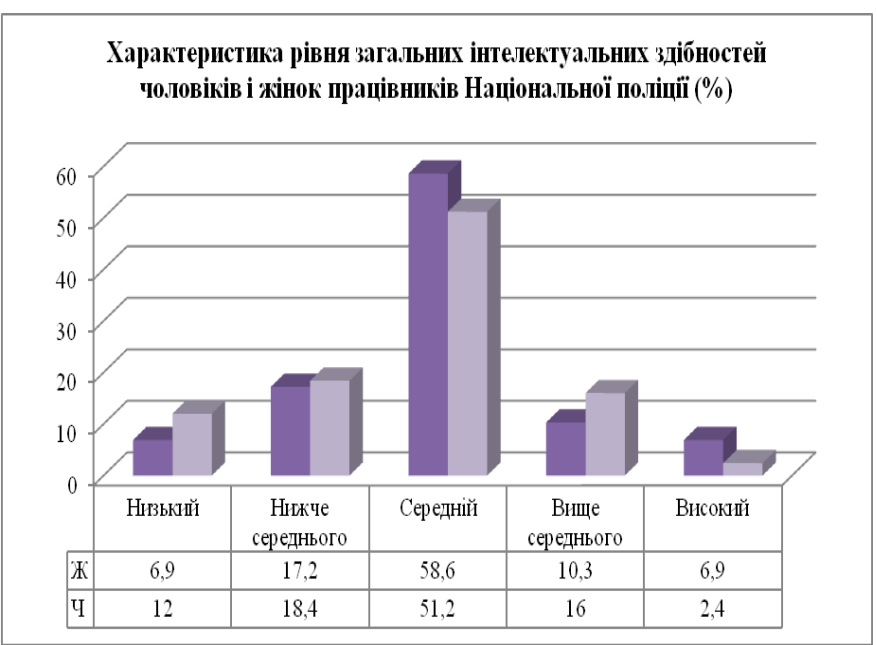

Рис.5

відповідатимуть групі з рівнем інтелекту ниж- 
че рівня «низький», однозначно не рекомендуються для несення служби в Національній поліції та на навчання в 3ВО МBC;

- особи, які ввійшли за своїми результатами в групи з рівнем інтелекту «низький» $\mathrm{i}$ «нижче середнього», мінімально відповідають вимогам до працівника Національної поліції і рекомендуються умовно, можуть бути прийняті на службу тільки при вираженому дефіциті кандидатів і при відсутності конкурсу до ЗВО МВС;

- особи з рівнем інтелекту «середній» $\mathrm{i}$ «вище середнього» в основному відповідають вимогам і рекомендуються до служби в підрозділах Національної поліції і навчання у ЗBO MBC;

- особи, які показали результати «високий» і вище, повністю відповідають вимогам до інтелектуальних здібностей і рекомендуються до служби в підрозділах Національної поліції і навчання у ЗВО МВС у першу чергу.

Завдання професійної орієнтації кандиPис. 7 датів на службу до Національної поліції зумовлені різним рівнем вимог до інтелекту й загальної обізнаності, що висуваються до працівників різних служб і підрозділів.

Очевидно, що обстежуваний, який має середній рівень інтелектуального розвитку, не може бути рекомендований на посаду або в підрозділ, служба в яких пов'язана $з$ високим інтелектуальним напруженням і вимагає солідного запасу відомостей загального характеру (загальної обізнаності) - оперативнорозшукова і слідча діяльність. Однак такий кандидат може бути рекомендований на роботу в інші підрозділи Національної поліції.

У зв'язку з вищевикладеним, при прогруп інших сфер діяльності ( $\mathbf{x}_{\text {ср }}$, балів)

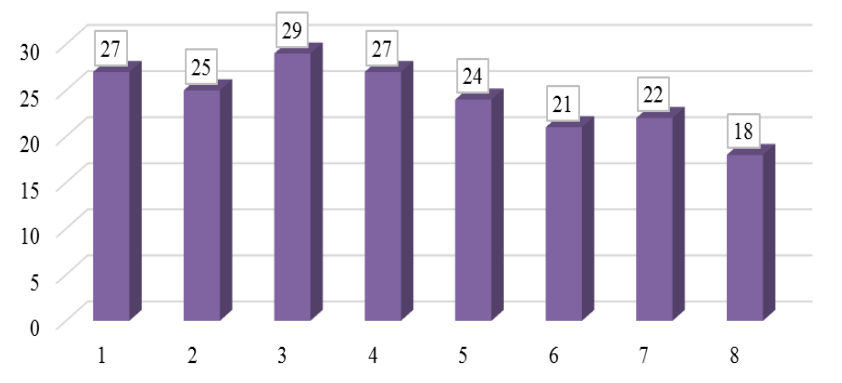

Табличя 6.

Усереднені показники за методикою КОТ у різних сферах діяльності ( $\mathbf{x}_{\text {ср }}$, балів)

\begin{tabular}{|c|c|c|c|}
\hline Група стандартизації [16, с.54] & $\begin{array}{c}\text { Умовні позна- } \\
\text { чення }\end{array}$ & M0 & $\boldsymbol{\sigma}$ \\
\hline Начальники відділів, лабораторій & 1 & 27 & 6,9 \\
\hline $\begin{array}{l}\text { Службовці центральних органів виконавчої влади (міністерств та ві- } \\
\text { домств) }\end{array}$ & 2 & 25 & 5,2 \\
\hline Студенти гуманітарних спеціальностей, чол. & 3 & 29 & 8,1 \\
\hline Студенти гуманітарних спеціальностей, жін. & 4 & 27 & 8,8 \\
\hline Студенти (спеціалізація електронне обладнання і програмування) & 5 & 24 & 4,3 \\
\hline Інженери електрозв'язку & 6 & 21 & 4,6 \\
\hline Працівники Національної поліції з вищою освітою & 7 & 22 & 5,7 \\
\hline Працівники Національної поліції з середньою освіт & 8 & 18 & 6,5 \\
\hline
\end{tabular}


фесійному відборі в підрозділи, пов'язані 3 оперативно-розшуковою та слідчою діяльністю, пропонується використовувати більш високі вимоги до рівня інтелекту кандидатів, у порівнянні 3 наведеними в Табл. 6. Доцільність цього зумовлена і відносно невисокими інтегральними показниками тесту КОТ у кандидатів (а потім і працівників поліції) в порівнянні $з$ працівниками інших сфер діяльності (Рис. 7). Очевидно, що в протиборстві кримінальних елементів і працівників Національної поліції рівень інтелекту в значній мірі визначає ефективність роботи останніх, особливо в оперативно-розшуковій та слідчій діяльності.

Висновки. Отже, узагальнюючи вищенаведене, можна зробити висновок про доцільність використання тесту КОТ у практиці при проведенні професійного відбору кандидатів на службу в Національну поліцію та навчання у ЗВО МВС. При цьому слід мати на увазі, що широке використання інтелектуальних тестів у світовій практиці для передбачення професійної успішності пов'язано з досить високою їх прогностичною надійністю, особливо щодо успішності навчання (інтелект i пов'язані з ним конструкти мають достатньо високу валідність).

Таким чином, наукове завдання щодо визначення факторів впливу на IП в даній статті вирішена; доведено, що інтегральний показник загальних інтелектуальних здібностей поліцейських залежить від освітніх та гендерних чинників. Встановлено, що особи з ви- щою освітою мають вищий загальний рівень обізнаності ( $\mathrm{p} \leq 0,014)$; більш успішно виконують числові завдання ( $\mathrm{p} \leq 0,001)$; володіють кращими здібностями смислових узагальнень ( $\leq 0,003)$; краще узагальнюють та аналізують ( $\mathrm{p} \leq 0,001)$ тощо. Порівняння складових інтелекту працівників Національної поліції чоловічої і жіночої статі показало, що жінки в середньому виконують більше завдань, ніж чоловіки; жінки $є$ більш здібними $(\mathrm{p} \leq 0,003)$; мають вищий рівень гуманітарної освіченості $(\mathrm{p} \leq 0,006)$, просторового орієнтування i абстрактно-логічного мислення $(\mathrm{p} \leq 0,018)$, а також $є$ більш здатними до числових операцій $(\mathrm{p} \leq 0,04)$. Частка жінок, які відповідають професійним вимогам і можуть бути рекомендованими кандидатами до роботи в поліції, становить $75,9 \%$, чоловіків $60,4 \%$.

Слід зазначити, що рівень інтелекту є лише одним із багатьох факторів, що визначають успішність професійної діяльності. Тому остаточний висновок про професійну придатність кандидата до служби в Національній поліції та навчання у 3ВО МВС необхідно робити на підставі результатів комплексного психологічного, психофізіологічного тестування, 3 огляду на специфіку службової діяльності. Перспективою подальшого дослідження є вивчення особистості працівника Національної поліції за допомогою інших психологічних методик, зокрема, Дж. Брунера «Визначення типів мислення та рівня креативності», тесту 
структури інтелекту Амтхауера, тесту емоційного інтелекту Н. Хола, тесту «Соціальний інтелект» Гілфорда, методики Е.П. Ільіна «Тепінг-тест» та ін.) тощо 3 метою визначення психодіагнотичних можливостей використання цих методик у практиці при проведенні професійного відбору кандидатів на службу в Національну поліцію та навчання у ЗВО МВС України.

\section{Перелік використаних джерел:}

1. Барко В. I., Остапович В.П. Шляхи оптимізації професійного психологічного відбору кандидатів на службу до Національної поліції України // Право і безпека. 2017. - № 1 (64). - C. 12-19.

2. Про Національну поліцію: Закон України від 2 липня 2015 p. № 580-VIII // База даних «Законодавство України»/ВР України. URL: http:// zakon0.rada.gov.ua/laws/show/580-19/page2\#n474 (дата звернення: 13.03.2016).

3. Методичні рекомендації з організації та проведення оцінювання учасників конкурсу для формування кадрового резерву на керівні посади в Міністерстві внутрішніх справ України, його територіальних органах та підрозділах // URL: https://www.naiau.kiev.ua/kadrovijrezerv-mvs.../metodichni-rekomendaciyi.doc (дата звернення: 13.03.2016).

4. Про затвердження Положення про організацію службової підготовки працівників Національної поліції України: Наказ МВС України від 26 січня 2016 р. №50 // База даних «Законодавство України»/BP України. URL: http://zakon0.rada.gov.ua/laws/show/z0260-16 (дата звернення: 13.03.2016).

5. Про організацію добору (конкурсу) та просування по службі поліцейських: наказ МВС України від 25 грудня 2015 р. № 1631 // База даних «Законодавство
України»/BP України. URL: http://zakon0.rada.gov.ua/ laws/show/z0049-16 (дата звернення: 13.03.2016).

6. Про затвердження Положення про порядок формування кадрового резерву на керівні посади в Міністерстві внутрішніх справ України, його територіальних органах та підрозділах: наказ МВС України від 17 вересня 2012 р. №808 // База даних «Законодавство України»/ВР України. URL: http://zakon3.rada.gov.ua/ laws/show/z1700-12 (дата звернення: 13.03.2016).

7. Бузин В. Н. Краткий отборочный тест. - М.: Смысл, 2012. - 298 с. (Психодиагностическая серия, выпуск. 4)

8. Бандурка А. М., Бочарова С. П., Землянская Е.В. Профессионализм и лидерство. - Харьков: Титул, 2006. $578 \mathrm{c}$.

9. Барко В. І., Клименко І.В., Криволапчук В.О. Профілактика адиктивної поведінки у працівників ОВС України: навч.посіб. - К.: Нац. акад. внутр. справ, 2009. $52 \mathrm{c}$.

10. Барко В. I., Остапович В.П., Барко В.В. Напрями вдосконалення професійної психологічної підготовки поліцейських Національної поліції України // Рsychological journal. - 2018. - № 4(14). - C. 9-19.

11. Гончаренко C. У. Український педагогічний словник / С.У. Гончаренко. - К.: Либідь, 1997. - 376 с.

12. Гельвецій K. А. Про людину, ïi розумові здібності і їі виховання. Твори у 2-х томах / К.А. Гельвецій / Перекл. 3 французської В. Підмогильного. - Т. 2. - К.: Основи, 1994. - 416 с.

13. Дидро Д. Энциклопедия. Просввещение. - К.: Алетейя, 2015. - 212 с.

14. Петровский A. В. Психология. Словарь / под ред. А.В. Петровского, Г.М. Ярошевського. - 2-е изд., испр. и доп. - М.: Политиздат, 1990. - 494 с.

15. Рубинштейн С. Л. Проблемы общей психологии / С.Л. Рубинштейн. - М.: Педагогика, 1973. - 432 с.

16. Теплов Б. М. Проблемы индивидуальных различий. - M.,1961. $-321 \mathrm{c}$.

17. Платонов К. К. Проблемы способностей. - М.: Наука, 1972. - 416 с. 
18. Anderson T. D. Every officer is a leader. New York: St. Lucie Press, 2000. - 4- 22 p.

19. Roberg R. R., Kuykendall J. Police organization and Management: Behavior, Theory and Processes. Pacific Grove, CA: Brooks; Cole Publishing Co, 1990. - 412 p.

\section{References (Transsliteration):}

1. Barko V. I., Ostapovych V.P. Shliakhy optymizatsii profesiinoho psykholohichnoho vidboru kandydativ na sluzhbu do Natsionalnoi politsii Ukrainy // Pravo i bezpeka. - 2017. - № 1 (64). - S. 12-19.

2. Pro Natsionalnu politsiiu: Zakon Ukrainy vid 2 lypnia 2015 r. № 580-VIII // Baza danykh «Zakonodavstvo Ukrainy»/VR Ukrainy. URL: http://zakon0.rada.gov.ua/ laws/show/580-19/page2\#n474 (data zvernennia: 13.03.2016).

3. Metodychni rekomendatsii $\mathrm{z}$ orhanizatsii ta provedennia otsiniuvannia uchasnykiv konkursu dlia formuvannia kadrovoho rezervu na kerivni posady $\mathrm{v}$ Ministerstvi vnutrishnikh sprav Ukrainy, yoho terytorialnykh orhanakh ta pidrozdilakh // URL: https://www.naiau.kiev.ua/kadrovij -rezerv-mvs.../metodichni-rekomendaciyi.doc

(data zvernennia: 13.03.2016).

4. Pro zatverdzhennia Polozhennia pro orhanizatsiiu sluzhbovoi pidhotovky pratsivnykiv Natsionalnoi politsii Ukrainy: Nakaz MVS Ukrainy vid 26 sichnia 2016 r. №50 // Baza danykh «Zakonodavstvo Ukrainy»/VR Ukrainy. URL: http://zakon0.rada.gov.ua/laws/show/z026016 (data zvernennia: 13.03.2016).

5. Pro orhanizatsiiu doboru (konkursu) ta prosuvannia po sluzhbi politseiskykh: nakaz MVS Ukrainy vid 25 hrudnia 2015 r. № 1631 // Baza danykh «Zakonodavstvo Ukrainy»/ VR Ukrainy. URL: http://zakon0.rada.gov.ua/laws/show/ z0049-16 (data zvernennia: 13.03.2016).

6. Pro zatverdzhennia Polozhennia pro poriadok formuvannia kadrovoho rezervu na kerivni posady $\mathrm{V}$ Ministerstvi vnutrishnikh sprav Ukrainy, yoho terytorialnykh orhanakh ta pidrozdilakh: nakaz MVS
Ukrainy vid 17 veresnia 2012 r. №808 // Baza danykh «Zakonodavstvo Ukrainy»/VR Ukrainy. URL: http:// zakon3.rada.gov.ua/laws/show/z1700-12 (data zvernennia: 13.03.2016).

7. Buzyn V. N. Kratkyi otborochnыi test. - M.: Smыsl, 2012. - 298 s. (Psykhodyahnostycheskaia seryia, vыpusk.

4)

8. Bandurka A. M., Bocharova S. P., Zemlianskaia E.V. Professyonalyzm y lyderstvo. - Kharkov: Tytul, 2006. $578 \mathrm{~s}$.

9. Barko V. I., Klymenko I.V., Kryvolapchuk V.O. Profilaktyka adyktyvnoi povedinky u pratsivnykiv OVS Ukrainy: navch.posib. - K.: Nats. akad. vnutr. sprav, 2009. $-52 \mathrm{~s}$.

10. Barko V. I., Ostapovich V.P., Barko V.V. Napryami vdoskonalennya profesIynoYi psihologIchnoYi pIdgotovki polItseyskih NatsIonalnoYi polItsIYi UkraYini // Psychological journal. - 2018. - \# 4(14). - S. 9-19.

11. Goncharenko S. U. UkraYinskiy pedagogIchniy slovnik / S.U. Goncharenko. - K.: LibId, 1997. - 376 s.

12. GelvetsIy K. A. Pro lyudinu, YiYi rozumovI zdIbnostI I YiYi vihovannya. Tvori u 2-h tomah / K.A. GelvetsIy / Perekl. z frantsuzskoYi V. PIdmogilnogo. - T. 2. - K.: Osnovi, 1994. - $416 \mathrm{~s}$.

13. Didro D. Entsiklopediya. Prosvveschenie. - K.: Aleteyya, 2015. - $212 \mathrm{~s}$.

14. Petrovskiy A. V. Psihologiya. Slovar / pod red. A.V. Petrovskogo, G.M. Yaroshevskogo. - 2-e izd., ispr. i dop. M.: Politizdat, 1990. - 494 s.

15. Rubinshteyn S. L. Problemyi obschey psihologii / S.L. Rubinshteyn. - M.: Pedagogika, 1973. - 432 s.

16. Teplov B. M. Problemyi individualnyih razlichiy. M.,1961. - $321 \mathrm{~s}$.

17. Platonov K. K. Problemyi sposobnostey. - M.: Nauka, 1972. $-416 \mathrm{~s}$.

18. Anderson T. D. Every officer is a leader. New York: St. Lucie Press, 2000. - 4- 22 r.

19. Roberg R. R., Kuykendall J. Police organization and Management: Behavior, Theory and Processes. Pacific Grove, CA: Brooks; Cole Publishing Co, 1990. - 412 p. 


\section{Smirnova Olga}

Ph. D. in Psychological Sciences, Associate Professor of the Department of Psychology and Pedagogy of the Odessa State University of Internal Affairs, Odessa (Ukraine)

\section{ANALYSIS OF THE LEVEL OF INTEGRAL INDEX OF GENERAL INTELLECTUAL ABILITIES DIAGNOSTICS IN THE CANDI- DATES FOR SERVICE IN THE NATIONAL POLICE AND FOR TRAINING AT HIGHER EDUCATION INSTITUTIONS OF THE MINISTRY OF INTERNAL AFFAIRS OF UKRAINE}

\section{ABSTRACT}

This article is devoted to the analysis of diagnosing the integral indicator of the level of general intellectual abilities with the Brief Tentative Selection Test, applied to the candidates for service in the National Police or for training at the Higher Educational Institutions of the Ministry of Internal Affairs of Ukraine in the course of their professional psychological selection. On the basis of the empirical data analysis, it was found that the level of education and the gender of candidates had the greatest impact on the value of the integral indicator of general intellectual abilities.

The estimates of the individual test indices for certain categories of candidates were also defined. The empirical evidence suggests that the higher education graduates, trained for the work in the criminal police forces, have a higher level of intellectual development and a better ability to further learning and cognitive activities, as compared to patrol police officers. That is, they have a higher level of cognitive activity and better abil- ities to acquire new knowledge and skills in similar forms of activities.

Data analysis proves that women are more intellectually capable; they have a higher level of humanitarian education, better spatial orientation and abstract-logical thinking, and are more capable of numerical operations.

The diagnostics of the critical points of intelligence proves that the criminal police cadets have a higher overall level of knowledge and development of linguistic abilities and have a higher level of humanitarian education ( $\mathrm{p} \leq 0.014)$ compared to the police patrol staff. The cadets are more successful in performing numerical tasks for the establishment of regularities with geometric figures $(p \leq 0,001)$; they are more informed ( $p$ $\leq 0,001)$; have a deeper connection between the functioning of intelligence and different linguistic skills ( $\mathrm{p} \leq 0.002)$; have higher abilities in semantic generalization $(\mathrm{p} \leq 0,003)$; have a higher level of technical intelligence, that is, they have better skills in using computer technologies, the Internet, etc. $(\mathrm{p} \leq 0,001)$; are much better at numerical operations $(\mathrm{p} \leq 0.001)$ and numerical regularities ( $p \leq 0.002$ ); have better abilities of synthesis and analysis of material, which enables them to abstract from specific phrases and switch to the sphere of interpretation of meanings, find the intersection of meanings, and then return to specific phrases again $(p \leq 0,002)$; have a much lower level of emotional destruction of cognitive processes $(\mathrm{p} \leq 0.002)$; are able to use the language correctly, are more literate, have better knowledge of 
foreign languages $(\mathrm{p} \leq 0,001)$; and have a higher level of mathematical abilities $(\mathrm{p} \leq 0,001)$.

This research enables us to conclude that it is advisable to use the Brief Tentative Selection Test when carrying out professional selection of candidates for service in the National Police and for training at the higher education institutions of the Ministry of Internal Affairs of Ukraine. It should be borne in mind that the widespread use of intellectual tests in the world practice for predicting professional success is due to their high reliability, especially when predicting the success of training (intelligence and related constructs give the highest validity of estimates $-r=0.45$ ).

Key words: integral indicator of general intellectual abilities, National Police, professional psychological selection of candidates for service in the National Police, professional psychological selection of candidates for training at the Higher Educational Institutions of the Ministry of Internal Affairs of Ukraine.

\section{Смирнова Ольга Михайловна}

Кандидат психологических наук, доиент кафедры психологии и педагогики, Одесский государственный университет внутренних дел, г. Одесса (Украина)

\section{АНАЛИЗ ДИАГНОСТИКИ УРОВНЯ \\ ИНТЕГРАЛЬНОГО ПОКАЗАТЕЛЯ \\ ОБЩИХ ИНТЕЛЛЕКТУАЛЬНЫХ \\ СПОСОБНОСТЕЙ КАНДИДАТОВ НА \\ СЛУЖБУ В НАЦИОНАЛЬНУЮ ПОЛИЦИЮ И ОБУЧЕНИЕ В \\ ОБРАЗОВАТЕЛЬНЫХ УЧРЕЖДЕНИЯХ МВД УКРАИНЫ}

Аннотация. Статья посвящена анализу диагностики уровня интегрального показателя общих интеллектуальных способностей кандидатов на службу в Национальную полицию или обучение в заведения высшего образования Министерства внутренних дел Украины по методике «Краткий ориентировочный отборочный тест» во время профессиональнопсихологического отбора. На основе анализа эмпирических данных определено, что наибольшее влияние на величину интегрального показателя общих интеллектуальных способностей имеет уровень образование и пол кандидатов, а также определены оценки индивидуального показателя методики для отдельных категорий кандидатов.

Ключевые слова: интегральный показатель общих интеллектуальных способностей, Национальная полиция, профессиональнопсихологический отбор кандидатов на службу в Национальную полицию, профессиональнопсихологический отбор кандидатов на обучение в заведениях высшего образования Министерства внутренних дел Украины.

Дата отримання статті: 21.04.2018 Дата рекомендації до друку: 15.05.2018 Дата оприлюднення: 24.05.2018 